DOI: http://dx.doi.org/10.33846/hn21016

http://heanoti.com/index.php/hn

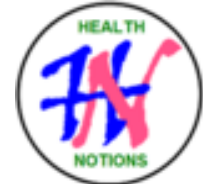

RESEARCH ARTICLE

URL of this article: http://heanoti.com/index.php/hn/article/view/hn21016

\title{
Administration of Iodized Salt, Counseling about Food Sources of Iodine and Goitrogenic, to Mothers who have Children in Primary School, Affect the Excretion of Urine Iodine
}

\author{
I Ketut Swirya Jaya ${ }^{1(\mathrm{CA})}$, Iswari Pauzi ${ }^{2}$ \\ ${ }^{1(\mathrm{CA})}$ Department of Nutrition, Poltekkes Kemenkes Mataram, Indonesia; swiryajaya@gmail.com (Corresponding \\ Author) \\ ${ }^{2}$ Department of Medical Laboratory, Poltekkes Kemenkes Mataram, Indonesia; iswari.pauzi69@gmail.com
}

\begin{abstract}
To overcome the problem of iodine deficiency, administration of iodized salt, counseling of iodized food sources and goitrogenic food are very important. The goal is to change the consumption of iodized and goitrogenic food sources and consume the recommended iodized salt, so that iodine intake is fulfilled and urinary iodine excretion becomes normal. This study was an experimental research, using pre-test and post-test with control group design. The sample size was 60 students of elementary school, consisting of 30 students. students for the treatment group and 30 students for the control group. In the treatment group, the mothers of the students were given iodized salt to give to their children, provided counseling about food sources that are rich in iodine and which are goitrogenic. The parameters measured were the consumption of iodine, protein and urinary iodine excretion in the phase before and after being treated, with a span of time for 3 weeks. Data collection on nutrient consumption was done through recall once in 24 hours. The level of iodine in the urine was measured using spectrophotometry, and the consumption of goitrogenic sources was measured through observation at the time of recall. The data were analyzed using t-test. Based on the results of the study it can be concluded that in Sedau Village, Narmada District, West Lombok Regency; giving iodized salt, counseling about iodized and goitrogenic food sources to mothers who have children in primary school.
\end{abstract}

Keywords: iodized salt; counseling; food sources of iodine; goitrogenic; excretion of urine iodine

\section{INTRODUCTION}

Disorders due to iodine deficiency not only cause mumps and cretinism, but also affect the decrease in the body's resistance to disease; stunted brain development (intellectual) and potentially reducing the level of intelligence or Intelligence Quotient (IQ); low productivity; even cause birth defects, both physical and mental; and growth disturbance. ${ }^{(1)}$ The occurrence of growth disturbances in children makes researchers interested in conducting research on the effect of iodized salt and counseling about food sources of iodine and goitrogenic substances to urine iodine excretion in primary school age children. Research on disorders due to iodine deficiency is often carried out in primary school-age children, aged 6-12 years because of their vulnerability to iodine deficiency considerations. Children in this age are in a period of growth and development, so attention to their nutritional needs is a strategic step, because the impact is directly related to the achievement of quality human resources. ${ }^{(2)}$

To overcome the problem of iodine deficiency, administration of iodized salt, counseling of iodized food sources and goitrogenic food are very important. The goal is to change the consumption of iodized and goitrogenic food sources and consume the recommended iodized salt, so that iodine intake is fulfilled and urinary iodine excretion becomes normal.

\section{METHODS}

This study was an experimental research, using pre-test and post-test with control group design. This research was conducted in Sedau Village, Narmada Subdistrict on elementary school students aged 9 to 12 years, or students in grades 4, grade 5 and grade 6, from May to August 20107. The sample size was 60 students, consisting of 30 students. students for the treatment group and 30 students for the control group. In the treatment group, the mothers of the students were given iodized salt to give to their children, provided counseling about food sources that are rich in iodine and which are goitrogenic. 
The parameters measured were the consumption of iodine, protein and urinary iodine excretion in the phase before and after being treated, with a span of time for 3 weeks. Data collection on nutrient consumption was done through recall once in 24 hours. The level of iodine in the urine was measured using spectrophotometry, and the consumption of goitrogenic sources was measured through observation at the time of recall. $^{(3)}$ The numerical data were presented in the form of mean and standard deviation ${ }^{(4)}$, then analyzed using t-test.

\section{RESULTS}

Table 1. The distribution of sex

\begin{tabular}{ccccc}
\hline \multirow{2}{*}{ Sex } & \multicolumn{2}{c}{ Treatment group } & \multicolumn{2}{c}{ Control group } \\
\cline { 2 - 5 } & Frequency & Percentage & Frequency & Percentage \\
\hline Male & 15 & 50 & 20 & 66.7 \\
\hline Female & 15 & 10 & 10 & 33.3 \\
\hline Total & 30 & 100 & 30 & 100 \\
\hline
\end{tabular}

Table 2. The distribution of age

\begin{tabular}{ccccc}
\hline \multirow{2}{*}{ Age } & \multicolumn{2}{c}{ Treatment group } & \multicolumn{2}{c}{ Control group } \\
\cline { 2 - 5 } & Frequency & Percentage & Frequency & Percentage \\
\hline$<10$ years old & 6 & 20 & 3 & 10 \\
\hline $10-12$ years old & 24 & 80 & 27 & 90 \\
\hline Total & 30 & 100 & 30 & 100 \\
\hline
\end{tabular}

Most of the respondents were 10 to 12 years old. This category was chosen with the consideration that children are more easily invited to communicate, especially regarding food consumption.

Table 3. The consumption of goitrogenic food in the treatment group

\begin{tabular}{ccccc}
\hline \multirow{2}{*}{ Goiterogenic consumption } & \multicolumn{2}{c}{ Treatment group } & \multicolumn{2}{c}{ Control group } \\
\cline { 2 - 5 } & Frequency & Percentage & Frequency & Percentage \\
\hline Yes & 22 & 73 & 7 & 23 \\
\hline No & 8 & 27 & 23 & 77 \\
\hline Total & 30 & 100 & 30 & 100 \\
\hline
\end{tabular}

Table 4. The consumption of goitrogenic food in the control group

\begin{tabular}{cccccc}
\hline \multirow{2}{*}{ Goiterogenic consumption } & \multicolumn{2}{c}{ Treatment group } & \multicolumn{2}{c}{ Control group } \\
\cline { 2 - 5 } & Frequency & Percentage & Frequency & \multicolumn{2}{c}{ Percentage } \\
\hline Yes & 19 & 63 & 17 & 56 \\
\hline No & 11 & 37 & 13 & 44 \\
\hline Total & 30 & 100 & 30 & 100 \\
\hline
\end{tabular}

In this study obtained data on goitogenic food consumption based on the results of recall and observation in the treatment group after being counseled about iodized and goitrogenic food sources. In the phase before treatment goitrogenic food consumption was $73 \%$, while in the phase after treatment it managed to decrease to $23 \%$. Whereas in the control group, there was a slight decrease from $63 \%$ to $56 \%$.

Table 5. Urinary iodine excretion in the treatment group

\begin{tabular}{ccccc}
\hline & $\mathrm{n}$ & Mean & Standard deviation & $\mathrm{p}$-value \\
\hline Before & 30 & 97.29 & 29 & 0.00 \\
After & 30 & 239.08 & 871 & 0.00 \\
\hline
\end{tabular}

Table 6. Urinary iodine excretion in the control group

\begin{tabular}{ccccc}
\hline & $\mathrm{n}$ & Mean & Standard deviation & $\mathrm{p}$-value \\
\hline Before & 30 & 117.30 & 11.85 & \multirow{2}{*}{0.00} \\
After & 30 & 243 & 92.2 & \\
\hline
\end{tabular}

In the treatment group, there were significant differences in the level of urinary iodine excretion, which was marked by $p$-value $=0.00$. The same thing also happened in the control group $(p$-value $=0.00)$.

Table 7. Distribution of protein consumption

\begin{tabular}{|c|c|c|c|c|c|c|c|c|}
\hline \multirow[t]{3}{*}{ Category } & \multicolumn{4}{|c|}{ Treatment group } & \multicolumn{4}{|c|}{ Control group } \\
\hline & \multicolumn{2}{|c|}{ Before } & \multicolumn{2}{|c|}{ After } & \multicolumn{2}{|c|}{ Before } & \multicolumn{2}{|c|}{ After } \\
\hline & $\mathrm{n}$ & $\%$ & $\mathrm{n}$ & $\%$ & $\mathrm{n}$ & $\%$ & $\mathrm{n}$ & $\%$ \\
\hline Mild deficit & 21 & 70 & 17 & 56 & 25 & 83 & 24 & 80 \\
\hline Exceeding adequacy & 0 & 0 & 3 & 11 & 0 & 0 & 0 & 0 \\
\hline Total & 30 & 100 & 30 & 100 & 30 & 100 & 30 & 100 \\
\hline
\end{tabular}


Protein deficiency will cause high T3 and free T4. With the feedback mechanism on TSH, the hormones from the thyroid gland will eventually decrease. In this study, especially in the treatment group, there was a significant difference $(\mathrm{p}<0.05)$, between before and after treatment, as indicated by an increase in the average protein intake from $47.91 \mu \mathrm{g} / \mathrm{L} \pm 6.54$ to $50.15 \mu \mathrm{g} / \mathrm{L} \pm 12.52$; while in the control group, almost no change occurred. Analysis of differences in urinary iodine excretion in the two groups showed that the administration of iodized salt, counseling about the consumption of iodized and goitogenic food sources affected urinary iodine excretion.

\section{DISCUSSION}

Goitrogenic is a substance that can inhibit the production or use of thyroid hormone. Substances that are goitrogenic many contained in food ingredients, such as cassava, sweet potatoes, cabbage, beans and mustard greens. ${ }^{(5)}$ In this study obtained data on goitogenic food consumption based on the results of recall and observation in the treatment group after being counseled about iodized and goitrogenic food sources. In the phase before treatment goitrogenic food consumption was $73 \%$, while in the phase after treatment it managed to decrease to $23 \%$. Whereas in the control group, there was a slight decrease from $63 \%$ to $56 \%$.

In the treatment group, there were significant differences in the level of urinary iodine excretion; the same thing also happened in the control group, but with a lower level of change. Iodine intake in daily food affects the adequacy of iodine in the body, the results of 24-hour recall in the treatment group did not differ statistically, but had a higher increase than the control group, which was limited in accordance with the daily iodine adequacy rate, which was recommended. ${ }^{(6)}$

Protein deficiency can affect various stages of hormone formation from the thyroid gland especially the hormone transport stage. T3 and T4 are bound by protein in serum, but only $0.3 \% \mathrm{~T} 4$ and $0.25 \% \mathrm{~T} 3$ are free. $^{(7)}$ Protein deficiency will cause high T3 and free T4, with a feedback mechanism in TSH, so that hormone levels from the thyroid gland eventually decrease. In this study, the treatment group experienced a significant change after being given an intervention, and this was also shown by an increase in the average protein intake, whereas in the control group there was almost no change. According to Mardiyanti ${ }^{(8)}$, lack of protein consumption, especially related to iodine, has nothing to do with the incidence of menarche in adolescents aged 12 years.

The results showed that administration of iodized salt, counseling about iodine and goitogenic food sources to mothers who have children in primary school, significantly influence the excretion of urine iodine. According to Mutalzimah $^{(9)}$, iodine intake is associated with urinary iodine excretion, but goiter is not related to iodine intake.

\section{CONCLUSION}

Based on the results of the study it can be concluded that in Sedau Village, Narmada District, West Lombok Regency; administration of iodized salt, counseling about 'food sources of iodine' and goitrogenic, to mothers who have children in primary school, affect the excretion of urine iodine.

\section{REFERENCES}

1. Ministry of Health of the Republic of Indonesia. Basic Health Research 2013 (Riset Kesehatan Dasar 2013). Jakarta: Ministry of Health of the Republic of Indonesia; 2013.

2. Efniati A, et al. Interrelations between Knowledge, Education Level and Availability of Iodized Salt Consumption at the Household Level, in the District of Sepatun Timur District, Tangerang Regency (Interelasi Pengetahuan, Tingkat Pendidikan, Ketersediaan Konsumsi Garam Beryodium di Tingkat Rumah Tangga di Wilayah Kecamatan Sepatun Timur, Kabupaten Tangerang). 2013.

3. Sartini D. The Relationship Between Urinary Iodine Excretion and Urinary Thiocyanate Excretion with Total Goiter Rate, Brebes Regency, Central Java (Hubungan Antara Ekskresi Yodium Urin dan Ekskresi Tiosianat Urin dengan Total Goiter Rate, Kabupaten Brebes, Jawa Tengah). Semarang: UNDIP; 2012.

4. Nugroho HSW. Descriptive data analysis for numerical data (Analisis data secara deskriptif untuk data numerik). Ponorogo: FORIKES; 2014.

5. Izati IM, Mahmudiono T. Patterns of Iodine and Goitrogenic Sources of Food Consumption with IDD in School Age Children in Ponorogo (Pola Konsumsi Makanan Sumber Yodium dan Goitrogenik dengan GAKY pada Anak Usia Sekolah di Ponorogo). Amerta Nutrition. 2017;1(2):88-97.

6. Budiman B. Current status of iodine in Indonesia: the need to sharpen targets (Status iodium di Indonesia saat ini: perlunya penajaman sasaran). Gizi Indon. 2017;35(1):1-9.

7. Kartasurya MI. Goitrogenic Substances. Semarang: RS Dr. Kariadi; 2006.

8. Rahayu MB. The relationship between energy consumption, protein and iodine with the incidence of menarche in young women, Magelang Regency (Hubungan konsumsi energy, protein dan yodium dengan kejadian menarche pada remaja putri, Kabupaten Magelang). Undergraduate Thesis. Semarang: UNDIP; 2012.

9. Multazimah, Mulyono B, Murti B, Azwar S. Iodine Intake, Urinary Iodine Concentration, and Goitre on Women of Childbearing Age at Endemic Areas of Iodine Deficiency (Asupan yodium urin, dan goiter pada wanitausia subur di daerah endemis defisiensi yodium). Kesmas, Jurnal Kesehatan Masyarakat Nasional. 2013;8(3):133-138. 